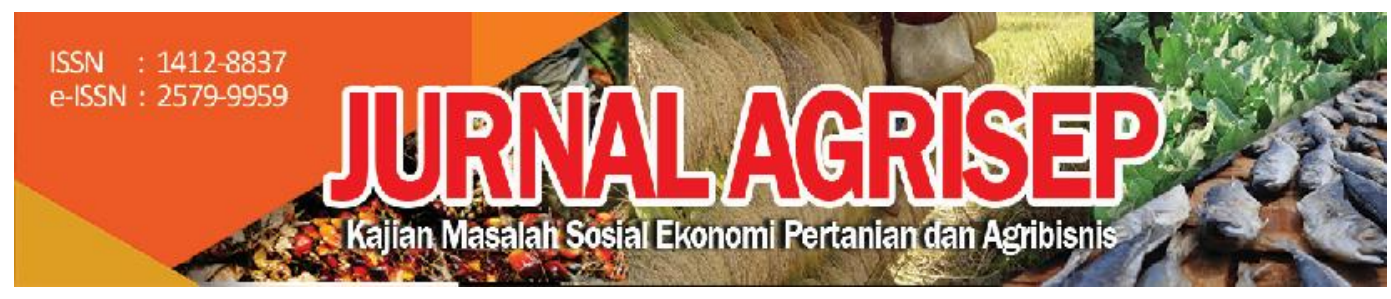

DOI: 10.31186/jagrisep.18.2.289-304

\title{
METODE PENYULUHAN PERTANIAN DALAM MENINGKATKAN PENGETAHUAN DAN KETERAMPILAN PETANI (STUDI KASUS DI KECAMATAN MAROS BARU KABUPATEN MAROS)
}

\section{Agricultural Extention Method for Improving Knowledge and Farmers Skills (Case Studi in New District Maros, District Maros)}

\author{
Andi Nur Imran ; ; Suhanniah; Bibiana Rini Widiati Giono \\ Program Studi Agribisnis, Fakultas Pertanian, Peternakan dan Kehutanan \\ Universitas Muslim Maros \\ Email: nurimran.95@yahoo.com
}

\begin{abstract}
Extensionist agents as one of the important spearheads in advancing agriculture in Indonesia. By counseling will provide information, knowledge, and skills to farmers in trying to farm. One of the factors in improving the knowledge and skills of farmers is to provide effective and efficient extension learning method. This study aims 1) Analyze the Method of agricultural Extension in Maros Baru Sub-district Maros Regency 2) Analyze the influence of Agricultural Extensionist Method in improving Farmers Knowledge and Skills in Maros Baru sub-district. This research was conducted for approximately 3 months, starting from May to July 2018, with the research location is in District Maros Baru. The sample in this study is the existing farmers in the District Maros Baru, with the sampling system by proportional sampling. The method of data analysis are: 1) Qualitative Descriptive Analysis and 2) Test $t$. The result of the research shows that: A) The Agriculture extension which is categorized as very high is Demplot, Anjangsana, Training and Field School, While the Method of learning extension that as high category is Temu wicara and comparative study. B) The overall agriculture extension Methode is influential in increasing the knowledge and skills of farmers.
\end{abstract}

Keywords: Method, Agriculture Extension, Knowledge and Skills

\section{ABSTRAK}

Penyuluh sebagai salah satu ujung tombak yang penting dalam memajukan pertanian di Indonesia. Dengan penyuluhan akan memberikan informasi, pengetahuan, 
dan keterampilan kepada petani dalam berusaha tani. Salah satu faktor dalam meningkatkan pengetahuan dan keterampilan petani adalah dengan memberikan metode pembelajaran penyuluhan yang efektif dan efisien. Penelitian ini bertujuan 1) Menganalisis metode Penyuluhan Pertanian di Kecamatan Maros Baru Kabupaten Maros 2) Menganalisis pengaruh metode Penyuluhan pertanian dalam meningkatkan Pengetahuan dan Keterampilan Petani di kecamatan Maros Baru. Penelitian ini dilaksanakan selama kurang lebih 3 bulan, dimulai pada bulan Mei sampai Juli 2018, dengan lokasi penelitian adalah di Kecamatan Maros Baru. Sampel dalam penelitian ini adalah Petani yang ada di Kecamatan Maros Baru, dengan sistem pengambilan sampel dengan cara proporsional sampling. Adapun metode analisis Data yaitu : 1) Analisis Deskriptif kualitatif dan 2) analisi Uji t. Hasil penelitian menunjukkan bahwa: A) Metode penyuluhan yang termasuk kategori sangat tinggi adalah Demplot, Anjangsana, Pelatihan dan Sekolah lapang (SL). Sedangkan Metode penyuluhan yang termasuk kategori tinggi adalah Temu wicara dan studi banding. B) Metode pembelajaran penyuluhan secara keseluruhan berpengaruh dalam meningkatkan pengetahuan dan keterampilan petani.

Kata kunci: Metode, Penyuluhan Pertanian, Pengetahuan dan Keterampilan

\section{PENDAHULUAN}

Penyuluh sebagai salah satu pihak yang penting dalam memajukan bidang pertanian di Indonesia harus memiliki pemahaman tentang cara dan teknik penyuluhan yang baik serta dapat diterima oleh petani sebagai klien. Harinta (2011) mengatakan bahwa penyuluhan adalah proses pemberian bantuan yang dilakukan dalam suasana hubungan tatap muka antara dua orang; yang satu karena keahliannya membantu yang lain untuk mampu mengatasi kesulitan yang dihadapinya. Dengan demikian keberhasilan bimbingan banyak ditentukan bagaimana penyuluhan itu dilakukan. Untuk dapat melakukan penyuluhan secara lebih terarah, penyuluh dituntut untuk benar-benar menguasai keterampilan dan pengetahuan dalam melaksanakan penyuluhan.

Penyuluhan yang baik sangat dipengaruhi oleh metode pembelajaran penyuluhan yang disampaikan kepada petani. Penyuluh yang mampu menerapkan metode dan teknik pembelajaran penyuluhan dengan baik akan memiliki kemampuan dalam meningkatan pengetahuan dan keterampilan petani dalam mengadopsi proses pembelajaran penyuluhan tersebut, sehingga petani dapat menerapkannya dalam system usaha tani yang dikembangkannya.

Perubahan paradigma metode dan teknik penyuluhan tersebut, telah memberikan pengaruh dalam penerimaan petani terhadap hasil inovasi dan metode penyuluhan tersebut dilapangan. Respon petani terhadap perubahan metode penyuluhan tersebut cukup baik, terbukti dengan tingkat adopsi terhadap penyuluhan tersebut telah banyak diterapkan oleh petani dilapangan. Sebagai contoh system tradisonal penanaman padi sudah mulai ditinggalkan dimana petani sudah memulai menerapkan dengan sistem jajar legowo sebagai 
sebuah inovasi metode penyuluhan baru dibidang penanaman padi. Namun masih ada juga metode penyuluhan yang belum memberikan perubahan perilaku yang nyata bagi petani dalam menerapkan sistem pertanian yang dikemangkannya, seperti metode penyuluhan studi banding, dimana hasil studi banding yang telah dilakukan masih banyak petani tidak menerapkannya dilapangan, sehingga metode tersebut masih dianggap belum bermanfaat secara keseluruhan oleh petani. Berdasarkan hal di atas, maka dilakukanlah penelitian yang berjudul Metode Penyuluhan pertanian dalam meningkatkan pengetahuan dan keterampilan petani di Kecamatan Maros Baru Kabupaten Maros.

\section{METODE PENELITIAN}

\section{Populasi dan Sampel Penelitian}

Populasi adalah seluruh petani yang ada di kecamatan Maros Baru Kabupaten Maros yang tergabung dalam kelompok tani yang berjumlah 32 kelompok tani, dengan jumlah anggota sebanyak 677 orang. Pengambilan sampel dilakukan dengan cara proporsional sampling, yang selanjutnya dari kelompok tani yang telah ditetapkan sebagai sampel akan dilakukan pengacakan sampel petani, dengan jumlah sampel sebanyak $10 \%$. Jumlah sampel dalam penelitian ini adalah 68 orang, seperti tersaji pada Tabel 1.

\section{Pengumpulan Data dan Metode Pelaksanaan Penelitian}

Data yang dikumpulkan terdiri dari data primer dan data sekunder. Data primer diperoleh dengan cara wawancara langsung dengan petani yang berada diwilayah Kecamatan Maros Baru yang telah ditetapkan sebelumnya, dengan menggunakan daftar pertanyaan (kuesioner). Sementara itu data sekunder diambil dari data Statistik, data potensi desa dan kecamatan, data dari dinas pertanian, dan data hasil penelitian. Metode pelaksanaan penelitian yang digunakan dalam penelitian ini terdiri atas : Observasi, Kuisioner, Wawancara dan Pengolahan Data.

\section{Analisis Data}

Data yang telah diperoleh dari hasil wawancara melalui quisioner diolah dengan metode analisis deskriptif kualitatif dan analisis kuantitatif, yang digambarkan sebagai berikut :

1. Untuk memperoleh rumusan Metode Penyuluhan di Kecamatan Maros Baru Kabupaten Maros, maka dilakukan analisis deskriptif kualitatif dengan metode skala likert 
Menurut Darmadi (2011), bahwa penentuan skala likert dapat dilakukan dalam beberapa tahapan sebagai berikut :

a. $\quad$ Menentukan nilai Skala Likert $=\mathrm{T} \times \mathrm{Pn}$

$\mathrm{T}=$ Total jumlah Responden yang memilih

Pn $=$ Pilihan angka skor Likert

Penentuan Persentase (\%) Index dengan rumus :

$P=\frac{f}{Y} \times 100 \%$

dimana P adalah Persentase (\%) yang dicari; f adalah Total Skor; dan $\mathrm{Y}$ adalah Nilai skort tertinggi

Tabel 1. Jumlah Populasi dan Sampel Responden pada Lokasi Penelitian di Kecamatan Maros Baru, Kabupaten Maros

\begin{tabular}{|c|c|c|c|c|c|}
\hline \multirow{2}{*}{ No } & \multirow{2}{*}{ Desa/Kelurahan } & \multicolumn{2}{|r|}{ Kelompok Tani } & \multirow{2}{*}{$\begin{array}{c}\text { Jumlah } \\
\text { (Populasi) }\end{array}$} & \multirow{2}{*}{$\begin{array}{c}\text { Sampel } \\
(10 \%)\end{array}$} \\
\hline & & Jumlah & Sampel (50\%) & & \\
\hline \multirow{3}{*}{1} & \multirow{3}{*}{ Palantikang } & \multirow{3}{*}{6} & 1. Karya Bersatu & 35 & 4 \\
\hline & & & 2. Padaidi & 27 & 3 \\
\hline & & & 3. Harapan Baru & 27 & 3 \\
\hline \multirow{3}{*}{2} & \multirow{3}{*}{ Baju Bodoa } & \multirow{3}{*}{6} & 1. Torannua & 21 & 2 \\
\hline & & & 2. Cinta Tani & 28 & 3 \\
\hline & & & 3. Jendela Rezki & 52 & 5 \\
\hline \multirow{3}{*}{3} & \multirow{3}{*}{ Baji Pamai } & \multirow{3}{*}{7} & 1. Paranuanta & 70 & 7 \\
\hline & & & 2. Paraikatte & 104 & 10 \\
\hline & & & 3. Sinar Tani & 45 & 5 \\
\hline \multirow{2}{*}{4} & \multirow{2}{*}{ Borikamase } & \multirow{2}{*}{4} & 1. Lekoala 1 & 63 & 6 \\
\hline & & & 2. Lekoala 2 & 28 & 3 \\
\hline 5 & Majannang & 2 & 1. Sipurennu & 83 & 8 \\
\hline \multirow{4}{*}{6} & \multirow{3}{*}{ Mattirotasi } & \multirow{3}{*}{7} & 1. Mamur & 35 & 4 \\
\hline & & & 2. Barugayya & 25 & 2 \\
\hline & & & 3. Semangat & 34 & 3 \\
\hline & Jumlah Sampel & 32 & 15 & 677 & 68 \\
\hline
\end{tabular}

Sumber: Data kelompok tani BPP-DPKP Kecamatan Maros Baru, 2017

Dari rumus di atas maka kita telah mengetahui kategori petani yang merasakan manfaat dari Metode penyuluhan pertanian di kecamatan Maros Baru.

b. Setelah itu, kita menentukan total nilai skor hasil penelitian, dan selanjutnya menentukan interval dan kategori hasil penelitian tersebut, dengan mengkategorikan dalam 4 kategori yaitu Sangat Tinggi, Tinggi, Sedang dan Rendah. Menurut Sudjono, (2011), menjelaskan bahwa ada beberapa tahapan dalam menentukan interval dan ketegori penelitian yang akan dilakukan, yaitu: 
i. Menentukan rentang, dengan rumus :

Rentang $=$ skor Tertinggi - Skor Terendah

Skor Tertinggi $=$ Nilai skor tertinggi $x$ jumlah sampel $(n)$

Skor Terendah $=$ Nilai skor terendah $\times$ jumlah sampel $(n)$

ii. Menentukan Banyaknya kategori kelas :

Kategori kelas adalah 4 kategori, yaitu Sangat Tinggi, Tinggi,

Sedang dan rendah

iii. Menentukan Panjang Interval, dengan rumus :

Interval = Jumlah responden / Jumlah skor likert

Adapun skor likert adalah :
a. Sangat Suka (4)
b. Suka (3)
c. Tidak Suka (2)
d. Sangat Tidak suka (1)

Dari langkah-langkah diatas, maka kita telah menentukan interval dan kategori dari penelitian tersebut, yang selanjutnya dibuatkan dalam kategori penelitian yang dapat dilihat pada tabel dibawah ini :

Tabel 2. Interval dan Kategori Metode Penyuluhan Pertanian

\begin{tabular}{ccl}
\hline No & Interval & \\
\hline 1 & $0 \%-24,99 \%$ & Kategori \\
2 & $25 \%-49,99 \%$ & Sedang \\
3 & $50 \%-74,99 \%$ & Tinggi \\
4 & $75 \%-100 \%$ & Sangat Tinggi \\
\hline
\end{tabular}

Sumber : Data Setelah Diolah, 2017

2. Untuk memperoleh hasil rumusan yang mempengaruhi Metode Penyuluhan dalam meningkatkan pengetahuan dan keterampilan petani, maka dilakukan analisis Uji t.

Analisis uji t untuk menjawab rumusan masalah penelitian ini dilakukan beberapa tahapan, yaitu: pertama, hasil wawancara dan Quisioner selanjutnya dilakukan pengolahan data, dengan mengelompokkan metode penyuluhan pertanian dalam beberapa indicator sesuai dengan tabel di bawah ini:

Tabel 3. Indikator Metode Penyuluhan Pertanian

\begin{tabular}{cccc}
\hline No & $\begin{array}{c}\text { Metode } \\
\text { Penyuluhan }\end{array}$ & Skor & \multicolumn{2}{c}{ Penjelasan } \\
\hline 1 & Anjangsana & 4 & $\begin{array}{l}\text { Jika kegiatan anjangsana sangat disenangi dan } \\
\text { bermanfaat bagi petani serta sangat sering diterapkan } \\
\text { dilapangan terhadap apa yang disampaikan } \\
\text { penyuluh kepada petani }\end{array}$ \\
\hline
\end{tabular}




\begin{tabular}{|c|c|c|c|}
\hline & 3 & $\begin{array}{l}\text { Jika kegiatan anjangsana disenangi dan bermanfaat } \\
\text { bagi petani serta biasa diterapkan dilapangan } \\
\text { terhadap apa yang disampaikan penyuluh kepada } \\
\text { petani }\end{array}$ \\
\hline & & 2 & $\begin{array}{l}\text { Jika kegiatan anjangsana kurang disenangi dan tidak } \\
\text { terlalu bermanfaat bagi petani serta jarang diterapkan } \\
\text { dilapangan terhadap apa yang disampaikan } \\
\text { penyuluh kepada petani }\end{array}$ \\
\hline & & 1 & Kegiatan anjangsana tidak disenangi oleh petani \\
\hline \multirow{4}{*}{\multicolumn{2}{|c|}{2 Pelatihan }} & 4 & $\begin{array}{l}\text { Jika kegiatan pelatihan sangat disenangi dan } \\
\text { bermanfaat bagi petani serta sangat sering } \\
\text { menerapkan dilapangan terhadap apa yang telah } \\
\text { didapatkan dari kegiatan pelatihan }\end{array}$ \\
\hline & & 3 & $\begin{array}{l}\text { Jika kegiatan pelatihan disenangi dan bermanfaat } \\
\text { bagi petani serta biasa diterapkan dilapangan } \\
\text { terhadap apa yang telah didapatkan dari kegiatan } \\
\text { pelatihan }\end{array}$ \\
\hline & & 2 & $\begin{array}{l}\text { Jika kegiatan pelatihan kurang disenangi dan tidak } \\
\text { terlalu bermanfaat bagi petani serta jarang diterapkan } \\
\text { dilapangan terhadap apa yang telah didapatkan dari } \\
\text { kegiatan pelatihan }\end{array}$ \\
\hline & & 1 & jika petani tidak menyenangi kegiatan pelatihan \\
\hline \multirow{4}{*}{\multicolumn{2}{|c|}{3 Demplot }} & 4 & $\begin{array}{l}\text { Jika kegiatan Demplot sangat disenangi dan } \\
\text { bermanfaat bagi petani serta sangat sering diterapkan } \\
\text { dilapangan terhadap apa yang telah didapatkan dari } \\
\text { kegiatan Demplot }\end{array}$ \\
\hline & & 3 & $\begin{array}{l}\text { Jika kegiatan Demplot disenangi dan bermanfaat bagi } \\
\text { petani serta biasa diterapkan dilapangan terhadap } \\
\text { apa yang telah didapatkan dari kegiatan Demplot }\end{array}$ \\
\hline & & 2 & $\begin{array}{l}\text { Jika kegiatan Demplot kurang disenangi dan tidak } \\
\text { terlalu bermanfaat bagi petani serta jarang diterapkan } \\
\text { dilapangan terhadap apa yang telah didapatkan dari } \\
\text { kegiatan Demplot }\end{array}$ \\
\hline & & 1 & jika petani tidak menyenangi kegiatan Demplot \\
\hline \multirow{3}{*}{\multicolumn{2}{|c|}{$4 \quad$ Studi Banding }} & 4 & $\begin{array}{l}\text { Jika kegiatan Studi banding sangat disenangi dan } \\
\text { bermanfaat oleh petani serta sangat sering diterapkan } \\
\text { dilapangan terhadap apa yang telah didapatkan dari } \\
\text { kegiatan Studi banding }\end{array}$ \\
\hline & & 3 & $\begin{array}{l}\text { Jika kegiatan Studi banding disenangi dan } \\
\text { bermanfaat bagi petani serta biasa diterapkan } \\
\text { dilapangan terhadap apa yang telah didapatkan dari } \\
\text { kegiatan Studi banding }\end{array}$ \\
\hline & & 2 & $\begin{array}{l}\text { Jika kegiatan Studi banding kurang disenangi dan } \\
\text { tidak terlalu bermanfaat bagi petani serta jarang } \\
\text { diterapkan dilapangan terhadap apa yang telah } \\
\text { didapatkan dari kegiatan Studi banding }\end{array}$ \\
\hline
\end{tabular}




\begin{tabular}{|c|c|c|c|}
\hline & & 1 & Jika petani tidak menyenangi kegiatan Studi banding \\
\hline \multirow[t]{4}{*}{5} & \multirow[t]{4}{*}{$\begin{array}{l}\text { Sekolah Lapang } \\
\text { (SL) }\end{array}$} & 4 & $\begin{array}{l}\text { Jika kegiatan sekolah lapang sangat disenangi dan } \\
\text { bermanfaat bagi petani serta sangat sering diterapkan } \\
\text { dilapangan terhada apa yang telah didapatkan dari } \\
\text { kegiatan Sekolah lapang }\end{array}$ \\
\hline & & 3 & $\begin{array}{l}\text { Jika kegiatan sekolah lapang disenangi dan } \\
\text { bermanfaat bagi petani serta biasa diterapkan } \\
\text { dilapangan terhadap apa yang telah didapatkan dari } \\
\text { kegiatan Sekolah lapang }\end{array}$ \\
\hline & & 2 & $\begin{array}{l}\text { Jika kegiatan sekolah lapang kurang disenangi dan } \\
\text { tidak terlalu bermanfaat bagi petani serta jarang } \\
\text { diterapkan dilapangan terhadap apa yang telah } \\
\text { didapatkan dari kegiatan Sekolah lapang }\end{array}$ \\
\hline & & 1 & jika petani tidak menyenangi kegiatan sekolah lapang \\
\hline \multirow[t]{4}{*}{6} & \multirow[t]{4}{*}{ Temu Wicara } & 4 & $\begin{array}{l}\text { Jika kegiatanTemu wicara sangat disenangi dan } \\
\text { bermanfaat bagi petani serta sangat sering diterapkan } \\
\text { dilapangan terhadap apa yang telah didapatkan dari } \\
\text { kegiatan Temu wicara }\end{array}$ \\
\hline & & 3 & $\begin{array}{l}\text { Jika kegiatan Temu wicara disenangi dan bermanfaat } \\
\text { bagi petani serta biasa diterapkan dilapangan } \\
\text { terhadap apa yang telah didapatkan dari kegiatan } \\
\text { Temu wicara }\end{array}$ \\
\hline & & 2 & $\begin{array}{l}\text { Jika kegiatanTemu wicara tidak terlalu disenangi dan } \\
\text { tidak terlalu bermanfaat bagi petani serta jarang } \\
\text { diterapkan dilapangan terhada apa yang telah } \\
\text { didapatkan dari kegiatan Temu wicara }\end{array}$ \\
\hline & & 1 & jika petani tidak menyenangi kegiatan Temu wicara \\
\hline
\end{tabular}

Sumber : Data Setelah Diolah, 2017

Setelah itu data tersebut dikelompokkan dalam bentuk angka yang disesuaikan dengan daftar pertanyaan Quisioner, yang selanjutnya dilakukan analisis uji $t$ dengan menggunakan program SPSS. Jika thitung $>t$ tabel, maka variabel metode penyuluhan tersebut telah berpengaruh dalam meningkatkan pengetahuan dan keterampilan petani.

\section{HASIL DAN PEMBAHASAN}

\section{Metode Penyuluhan Pertanian Di Kecamatan Maros Baru}

\section{Metode Penyuluhan Anjangsana}

Metode penyuluhan anjangsana adalah cara atau kegiatan yang dilakukan oleh penyuluh pertanian dalam mengunjungi petani atau kelompok tani dalam menyampaikan informasi, pengetahuan dan keterampilan kepada petani diwilayahnya masing-masing serta diikuti oleh petani atau kelompok tani 
tersebut. Dari hasil penelitian dapat dikatakan bahwa Metode penyuluhan anjangsana yang sangat disukai oleh petani sebanyak 41 orang dengan nilai 164, dan yang hanya disukai sebanyak 14 orang dengan nilai 42 .

Tabel 4. Hasil Kegiatan Metode Penyuluh Pertanian Anjangsana kepada Petani pada lokasi penelitian

\begin{tabular}{ccccl}
\hline No & $\begin{array}{c}\text { Skor } \\
(\mathrm{A})\end{array}$ & $\begin{array}{c}\text { Jumlah Petani } \\
(\mathrm{B})\end{array}$ & $\begin{array}{c}\text { Total } \\
(\mathrm{A} \times \mathrm{B})\end{array}$ & \multicolumn{1}{c}{ Kategori } \\
\hline 1 & 4 & 41 & 164 & Sangat Suka \\
2 & 3 & 14 & 42 & Suka \\
3 & 2 & 8 & 16 & Tidak Suka \\
4 & 1 & 5 & 5 & Sangat Tidak Suka \\
\hline & Jumlah & 68 & 227 & \\
\hline
\end{tabular}

Sumber: Data Primer Setelah diolah, 2017

Hasil berdasarkan Tabel 4 menunjukkan bahwa sangat sedikit petani tidak menyukai metode anjangsana yaitu sebanyak 13 orang dengan nilai 21. Dengan demikian bahwa secara keseluruhan petani sangat menyukai Metode penyuluhan anjangsana dengan index persentase $83,45 \%$ dan termasuk dalam kategori sangat tinggi. Hal ini dapat dikatakan bahwa petani telah merasakan manfaat dari kegiatan metode anjangsana yang dilakukan oleh penyuluh sehingga apa yang disampaikan penyuluh kepada petani pada umumnya dapat diserap oleh petani dengan baik serta dapat melaksanakan dalam kegiatan budidaya pertanian yang dilakukannya. Hal ini dapat dikatakan bahwa metode penyuluhan anjangsana yang dilakukan oleh penyuluh telah memberikan banyak informasi serta telah menambah pengetahuan dan keterampilan petani secara keseluruhan. Hal ini juga sesuai dengan hasil penelitian Purnaningsih (2012), yang menyatakan bahwa metode penyuluhan petanian sangat dirasakan manfaatnya bagi petani sehingga petani merasa memiliki banyak informasi dan pengetahuan yang didapat dari metode penyuluhan pertanian, dimana salah satu adalah metode anjangsana.

\section{Metode Penyuluhan Pelatihan}

Metode penyuluhan pelatihan adalah suatu cara atau kegiatan penyuluhan pertanian yang dilakukan didalam ruangan maupun diluar ruangan dalam rangka memberikan informasi, pengetahuan dan keterampilan kepada petani yang dilakukan dengan cara pemberian materi kepada peserta oleh Narasumber atau fasilitator. Narasumber atau fasilitator yang dimaksud salah satunya adalah penyuluh, Dari hasil penelitian dapat dikatakan bahwa metode penyuluhan pelatihan yang sangat disukai oleh petani sebanyak 37 
orang dengan total nilai 148 , dan yang hanya menyukai sebanyak 17 orang dengan total nilai 51 .

Tabel 5. Hasil Kegiatan Metode Pelatihan pada lokasi penelitian

\begin{tabular}{cccrl}
\hline No & $\begin{array}{c}\text { Skor } \\
(\mathrm{A})\end{array}$ & $\begin{array}{c}\text { Jumlah Petani } \\
(\mathrm{B})\end{array}$ & $\begin{array}{c}\text { Total } \\
(\mathrm{A} \times \mathrm{B})\end{array}$ & \multicolumn{1}{c}{ Kategori } \\
\hline 1 & 4 & 37 & 148 & Sangat Suka \\
2 & 3 & 17 & 51 & Suka \\
3 & 2 & 10 & 20 & Tidak Suka \\
4 & 1 & 4 & 4 & Sangat Tidak Suka \\
\hline \multicolumn{2}{c}{ Jumlah } & 68 & 223 & \\
\hline
\end{tabular}

Sumber : Data Primer Setelah Diolah, 2017

Berdasarkan Tabel 5, petani yang tidak menyukai metode penyuluhan pelatihan jumlahnya sebanyak 14 orang dengan nilai total 24 . Dengan demikian bahwa secara keseluruhan petani sangat menyukai Metode penyuluhan Pelatihan dengan index persentase $81,96 \%$ dan termasuk dalam kategori sangat tinggi. Hal ini juga dapat dikatakan bahwa petani telah merasakan manfaat dari kegiatan metode penyuluhan pelatihan yang dilakukan oleh instansi pemerintah maupun penyuluh pada umumnya dapat diserap oleh petani dengan baik serta dapat melaksanakan dalam kegiatan-kegiatan budidaya pertanian yang dilakukannya, sehingga metode penyuluhan pelatihan telah memberikan banyak informasi serta telah menambah pengetahuan dan keterampilan petani secara keseluruhan. Hal ini juga sesuai dengan hasil penelitian Sudarso,et, al, (2014), yang menyatakan bahwa petani di Kabupaten Jember telah mendapatkan banyak pengetahuan dan informasi serta menerapkan hasil metode penyuluhan pelatihan yang dilakukan oleh pemerintah khususnya Dinas Pertanian setempat, sehingga petani semakin berinovasi dalam kegiatan-kegiatan budidaya pertanian yang dilakukannya

\section{Metode Penyuluhan Demplot}

Metode penyuluhan Demplot/ Demonstrasi adalah metode kegiatan penyuluhan pertanian yang dilakukan dengan cara peragaan atau memberikan contoh langsung kepada petani yang bertujuan untuk memberikan pengetahuan dan keterampilan petani, sehingga dapat diterapkan dalam kegiatan sistem usaha taninya. Dari hasil penelitian dapat dikatakan bahwa metode penyuluhan Demplot paling banyak petani yang sangat menyukainya yaitu sebanyak 52 orang dengan nilai total 208, dan petani yang hanya menyukai saja metode penyuluhan Demplot/Demonstrasi sebanyak 10 orang dengan nilai total 30 . Untuk lebih jelasnya dapat dilihat pada tabel dibawah ini : 
Tabel 6. Hasil Kegiatan Pembelajaran Penyuluhan Demplot pada lokasi penelitian

\begin{tabular}{ccccl}
\hline No & $\begin{array}{c}\text { Skor } \\
(\mathrm{A})\end{array}$ & $\begin{array}{c}\text { Jumlah Petani } \\
(\mathrm{B})\end{array}$ & $\begin{array}{c}\text { Total } \\
(\mathrm{A} \times \mathrm{B})\end{array}$ & \multicolumn{1}{c}{ Kategori } \\
\hline 1 & 4 & 52 & 208 & Sangat Suka \\
2 & 3 & 10 & 30 & Suka \\
3 & 2 & 5 & 10 & Tidak Suka \\
4 & 1 & 1 & 1 & Sangat Tidak Suka \\
\hline \multicolumn{2}{c}{ Jumlah } & 68 & 249 & \\
\hline
\end{tabular}

Sumber : Data Primer Setelah Diolah, 2017

Tabel 6 menunjukkan bahwa petani yang tidak menyukai metode penyuluhan Demplot/Demonstrasi jumlahnya sebanyak 6 orang dengan nilai total 11. Dengan demikian bahwa secara keseluruhan petani juga sangat menyukai Metode penyuluhan Demplot/Demonstrasi dengan index persentase $91,54 \%$ dan termasuk dalam kategori sangat tinggi. Hal ini juga dapat dikatakan bahwa petani telah merasakan manfaat dari metode penyuluhan Demplot/Demonstrasi yang dilakukan oleh instansi pemerintah maupun penyuluh karena petani langsung melihat dengan mata kepalanya sendiri sehingga penerapan informas dan pengetahuan langsung dapat diserap dengan baik. Selain itu petani juga dapat langsung mempraktekkannya dilapangan setelah metode demplot/Demonstrasi tersebut dilakukan. Dari metode penyuluhan Demplot/Demonstrasi telah memberikan banyak tambahan pengetahuan dan ketreampilan petani dalam proses dan kegiatan budidaya pertanian yang dilakukannya. Hal ini juga sesuai dengan hasil penelitian Travino, (2013), yang menyatakan bahwa petani di Kota Kupang telah menerapkan berbagai Demplot/Demonstrasi yang dilakukan oleh pemerintah daerah dalam hal ini Dinas Pertanian setempat dalam kegiatan budidaya pertanian yang dilakukannya, sehingga metode Demplot tersebut telah memberikan konstribusi yang tinggi dalam peningkatan budidaya pertanian di Kota Kupang Nusa Tenggara Timur.

\section{Metode Penyuluhan Studi Banding}

Metode penyuluhan Studi banding adalah kegiatan penyuluhan pertanian yang dilakukan dalam rangka tukar informasi, pengetahuan dan keterampilan antar kelompok petani diluar wilayah budidaya pertaniannya. Dari hasil penelitian dapat dikatakan bahwa metode penyuluhan studi banding yang sangat disukai oleh petani hanya 20 orang dengan total nilai 80 , dan hanya menyukai kegiatan metode penyuluhan studi banding adalah sebanyak 22 
petani dengan total nilai 66 . Untuk lebih jelasnya dapat dilihat pada tabel dibawah ini :

Tabel 7. Hasil Metode Penyuluhan Studi Banding pada lokasi penelitian

\begin{tabular}{ccccl}
\hline No & $\begin{array}{c}\text { Skor } \\
(\mathrm{A})\end{array}$ & $\begin{array}{c}\text { Jumlah Petani } \\
(\mathrm{B})\end{array}$ & $\begin{array}{c}\text { Total } \\
(\mathrm{A} \times \mathrm{B})\end{array}$ & \multicolumn{1}{c}{ Kategori } \\
\hline 1 & 4 & 20 & 80 & Sangat Suka \\
2 & 3 & 22 & 66 & Suka \\
3 & 2 & 17 & 34 & Tidak Suka \\
4 & 1 & 9 & 9 & Sangat Tidak Suka \\
\hline \multicolumn{2}{r}{ Jumlah } & 68 & 189 & \\
\hline
\end{tabular}

Sumber : Data Primer Setelah Diolah, 2017

Berdasarkan Tabel 7, petani yang tidak menyukai metode penyuluhan studi banding cukup banyak yaitu sekitar 26 orang dengan total nilai 44 . Dengan demikian bahwa secara keseluruhan petani menyukai Metode penyuluhan studi banding dengan index persentase 69,49\% dan termasuk dalam kategori tinggi. Hal ini juga dapat dikatakan bahwa petani masih merasakan manfaat metode studi banding yang selama ini diikutinya, namun masih banyak petani setelah studi banding tidak menerapkan apa yang didapat dari metode atau kegiatan tersebut. Hal ini dikarenakan bahwa kegiatan studi banding yang selama ini diikuti oleh petani orientasinya lebih banyak jalanjalan, dibandingkan proses pembelajarannya, sehingga petani tidak terlalu termotivasi dalam mengikuti kegiatan metode studi banding Namun dari metode penyuluhan studi banding telah memberikan banyak pengetahuanpengetahuan yang baru serta ketreampilan kepada petani dalam budidaya pertanian yang dilakukannya seperti sistem budidaya Tanaman Padi SRI, jajar legowo 3:1, dan $4: 1$, dan lain-lainnya. Hal ini juga sesuai dengan hasil tulisan Kurniawan, (2014), yang menyatakan bahwa berbagai metode penyuluhan pertanian telah memberikan kontribusi terhadap meningkatnya sistem budidaya pertanian yang dikembangkan oleh petani. Meskipun metode penyuluhan studi banding masih kurang signifikan memberikan kontribusi terhadap meningkatnya inovasi petani dalam membudidayakan sistem pertanian yang dilakukannya, namun petani cukup antusias dalam mengikuti metode atau kegiatan penyuluhan tersebut.

\section{Metode Penyuluhan Sekolah Lapang (SL)}

Metode penyuluhan sekolah lapang (SL) adalah kegiatan penyuluhan pertanian dalam proses diklat kepada petani secara singkat yang dilakukan oleh kelompok tani dilapangan bersama pemandu lapangan (PL) atau penyuluh. Dari hasil penelitian bahwa metode penyuluhan sekolah lapang (SL) yang sangat disukai oleh petani hanya 30 orang dengan total nilai 120 , dan hanya menyukai 
kegiatan metode penyuluhan sekolah Lapang (SL) adalah sebanyak 19 petani dengan total nilai 57 . Untuk lebih jelasnya dapat dilihat pada tabel dibawah ini :

Tabel 8. Hasil Metode Penyuluhan Sekolah Lapang (SL) pada lokasi penelitian

\begin{tabular}{ccccl}
\hline No & $\begin{array}{c}\text { Skor } \\
(\mathrm{A})\end{array}$ & $\begin{array}{c}\text { Jumlah Petani } \\
(\mathrm{B})\end{array}$ & $\begin{array}{c}\text { Total } \\
(\mathrm{A} \times \mathrm{B})\end{array}$ & \multicolumn{1}{c}{ Kategori } \\
\hline 1 & 4 & 30 & 120 & Sangat Suka \\
2 & 3 & 19 & 57 & Suka \\
3 & 2 & 11 & 22 & Tidak Suka \\
4 & 1 & 8 & 8 & Sangat Tidak Suka \\
\hline \multicolumn{2}{c}{ Jumlah } & 68 & 207 & \\
\hline
\end{tabular}

Sumber : Data Primer Setelah Diolah, 2017

Berdasarkan Tabel 8, petani yang tidak menyukai metode penyuluhan sekolah lapang sebanyak 19 orang dengan total nilai 30. Dengan demikian bahwa secara keseluruhan petani sangat menyukai Metode penyuluhan sekolah lapang dengan index persentase $76,10 \%$ dan termasuk dalam kategori sangat tinggi. Hal ini juga dapat dikatakan bahwa petani sangat merasakan manfaat metode sekolah lapang yang selama ini diikutinya, sehingga memberikan kontribusi terhadap banyaknya informasi dan pengetahuan petani terhadap budidaya pertanian yang dilakukannya. Olehnya itu petani menganggap bahwa metode penyuluhan sekolah lapang (SL) ini cukup bermanfaat bagi mereka karena dipratekkan secara langsung dilapangan dimana pelaksanaannya langsung dilihat oleh petani,sehingga semakin mudah dipahami oleh petani. Hal ini juga sesuai dengan hasil tulisan Purwono, (2013), yang menyatakan sekolah lapang merupakan komponen penting dalam metode penyuluhan pertanian, karena metode tersebut dilaksanakan langsung dilapangan dengan praktek kerja sehingga petani lebih mudah memahami apa yang dsampaikan oleh penyuluh atau instansi terkait dalam hal ini Dinas Pertanian.

\section{Metode Penyuluhan Temu Wicara}

Metode penyuluhan Temu Wicara adalah kegiatan penyuluhan pertanian yang dilakukan pertemuan dua arah antara kelompok tani, pemerintah, dan swasta dengan membahas hal-hal yang berkaitan dengan system usaha tani, kebijakan pemerintah dibidang usaha tani pertanian, dan lain-lain. Dari hasil penelitian dapat dikatakan bahwa metode penyuluhan temu wicara yang sangat disukai oleh petani hanya 23 orang dengan total nilai 92, dan hanya menyukai kegiatan metode penyuluhan temu wicara adalah sebanyak 15 petani dengan total nilai 60. Untuk lebih jelasnya dapat dilihat pada tabel dibawah ini : 
Tabel 9. Hasil Metode Penyuluhan Temu Wicara pada lokasi penelitian

\begin{tabular}{ccccl}
\hline No & $\begin{array}{c}\text { Skor } \\
(\mathrm{A})\end{array}$ & $\begin{array}{c}\text { Jumlah Petani } \\
(\mathrm{B})\end{array}$ & $\begin{array}{c}\text { Total } \\
(\mathrm{A} \times \mathrm{B})\end{array}$ & \multicolumn{1}{c}{ Kategori } \\
\hline 1 & 4 & 23 & 92 & Sangat Suka \\
2 & 3 & 20 & 60 & Suka \\
3 & 2 & 15 & 30 & Tidak Suka \\
4 & 1 & 10 & 10 & Sangat Tidak Suka \\
\hline \multicolumn{2}{r}{ Jumlah } & 68 & 192 & \\
\hline
\end{tabular}

Sumber : Data Primer Setelah Diolah, 2017

Tabel 9 menunjukkan bahwa petani yang tidak menyukai metode penyuluhan sekolah lapang sebanyak 25 orang dengan total nilai 40 . Dengan demikian bahwa secara keseluruhan petani menyukai Metode penyuluhan temu wicara dengan index persentase 70,59 \% dan termasuk dalam kategori tinggi. Hal ini karena pembelajaran penyuluhan temu wicara ini pada umumnya dilaksanakan melalui ceramah atau dialog. Sedangkan petani sudah mulai jenuh dan bosan ketika kegiatan dilaksanakan dengan ceramah atau teori. Petani menyukai jika kegiatan tersebut dilaksanakan secara langsung dilapangan atau dengan kata lain langsung dilihat pelaksanaannya dilapangan. Hal ini juga sesuai dengan hasil tulisan Kusmiyati, dkk, 2014 yang menyatakan temu wicara yang merupakan salah satu metode penyuluhan pertanian lebih banyak dilakukan secara formalitas saja oleh pemerintah atau penyuluh sehingga petani masih kurang menerapkan dilapangan terhadap apa yang telah diterima dari metode penyuluhan temu wicara terseut, namun secara keseluruhan juga telah memberikan kontribusi dalam peningkatan pengetahuan petani.

Data yang telah diuraikan diatas, untuk seluruh metode penyuluhan pertanian di Kecamatan Maros Baru, maka dibuatlah rekapitulasi metode Penyuluhan pertanian di kecamatan Maros Baru, seperti dilihat pada Tabel 10. Berdasarkan Tabel 10 ini, metode Penyuluhan pertanian di Kecamatan Maros Baru yang memiliki kategori sangat tinggi dan pengaruhnya paling besar dan signifikan adalah metode pembelajaran penyuluhan Demplot, Anjangsana, Pelatihan dan Sekolah lapang dengan total skor secara berturut-turut adalah 249, 227, 223 dan 207. Sedangkan metode penyuluhan pertanian yang memiliki kategori tinggi adalah temu wicara dan studi banding dengan total skor sebanyak 192 dan 189. Hal ini berdasarkan bahwa kegiatan metode Demplot, anjangsana, pelatihan dan sekolah lapang pelaksanaan dilakukan langsung dilapangan dengan memberikan contoh-contoh pelaksanaannya, sehingga petani lebih mudah menyerapnya secara langsung, dan hasil metode tersebut juga telah banyak dipraktekkan dan dilaksanakan oleh petani terhadap sistem budidaya pertanian yang dikembangkannya. Sedangkan kegiatan studi banding dan temu wicara tidak terlalu significan memberikan pengaruh yang sangat besar bagi petani, karena menurut petani metode tersebut hanya dilaksanakan 
secara seremonial saja dan terkesan menghabiskan anggaran pemerintah, serta metode tersebut lebih banyak melibatkan ketua atau sekretaris kelompok tani saja tanpa melibatkan petani secara keseluruhan. Selain itu, petani beranggapan bahwa metode studi banding dan temu wicara dilaksanakan tidak berdasarkan kebutuhan dan keinginan petani dalam artian bahwa metode tersebut dilaksanakan masih secara top down.

Tabel 10. Rekapitulasi Metode Pembelajaran Penyuluh Pertanian di Kecamatan Maros Baru

\begin{tabular}{clcl}
\hline No & Metode Penyuluhan & Jumlah Skor Total & \multicolumn{1}{c}{ Kategori } \\
\hline 1 & Anjangsana & 227 & Sangat Tinggi \\
2 & Pelatihan & 223 & Sangat Tinggi \\
3 & Demplot & 249 & Sangat Tinggi \\
4 & Studi Banding & 189 & Tinggi \\
5 & Sekolah Lapang & 207 & Sangat Tinggi \\
6 & Temu Wicara & 192 & Tinggi \\
\hline
\end{tabular}

Sumber : Data Primer setelah diolah, 2017

\section{Pengaruh Metode Penyuluhan Pertanian Dalam Meningkatkan Pengetahuan dan Keterampilan Petani}

Secara keseluruhan Metode penyuluhan pertanian telah berpengaruh dalam meningkatkan pengetahuan dan keterampilan petani. Hal ini data dilihat dari nilai $t$ hitung $>t$ tabel akan secara siqnifikan mempengaruhi untuk semua nilai metode Penyuluhan pertanian (lihat Tabel 11).

Tabel 11. Hasil Uji $\mathrm{T}$ pengaruh Metode Penyuluhan pertanian dalam meningkatkan pengetahuan dan keterampilan

\begin{tabular}{lccc}
\hline \multicolumn{1}{c}{ Model } & $\mathrm{t}$ hit. & $\mathrm{t}$ tab. & Siq \\
\hline Constanta & 1,316 & & 0,193 \\
Anjangsana & 2,887 & & 0,005 \\
Pelatihan & 2,819 & & 0,006 \\
Demplot & 3,369 & 1,670 & 0,002 \\
Studi Banding & 1,976 & & 0,053 \\
Sekolah Lapang & 2,264 & & 0,027 \\
Temu Wicara & 2,138 & & 0,036 \\
\hline
\end{tabular}

Sumber : Data Primer setelah diolah, 2017

Berdasarkan Tabel 11 dapat dikatakan bahwa semua metode penyuluhan pertanian berpengaruh positif terhadap peningkatan pengetahuan dan keterampilan petani. Dari hasil tael diatas juga dapat dikatakan bahwa metode penyuluhan Demplot memiliki pengaruh yang terbesar dalam meningkatkan 
pengetahuan dan keterampilan petani. Hal ini menurut petani bahwa pelaksanaan metode Demplot secara langsung dapat dilihat dilapangan terhadap apa yang dilakukan dari kegiatan Demplot tersebut. Petani langsung mempraktekkan berbagai kegiatan Demplot yang dilakukan, sehingga pengetahuan maupun keterampilan yang didapat dari kegiatan Demplot langsung dengan mudah diterima oleh petani. Petani lebih mudah memahaminya jika langsung melihatnya serta mempraktekkannya. Pelaksanaan kegiatan Demplot yang selama ini dilakukan serta diikuti oleh petani merupakan kondisi dan permasalahan yang banyak dialami oleh petani dilapangan seperti system pengendalian hama, sistem perbenihan, system pemupukan berimbang, dan lain-lainya, yang kesemuanya itu merupakan hasil pengalaman yang telah dilakukan oleh petani, sehingga permasalahanpermasalahan pengelolaan pertanian yang dilakukannya mendapatkan jalan keluar dengan dilakukannya kegiatan Demplot tersebut. Sedangkan metode studi banding memiliki pengaruh yang paling kecil karena petani menganggap bahwa metode tersebut masih dilaksanakan secara seremonial saja dan tidak berdasarkan kebutuhan dan keinginan petani, serta pelaksanaannya masih bersifat Top Down.

\section{SIMPULAN DAN SARAN}

Berdasarkan hasil diatas, maka dapat ditarik kesimpulan sebagai berikut :

1. Metode penyuluhan pertanian yang termasuk kategori sangat tinggi adalah Demplot, Anjangsana, Pelatihan dan Sekolah lapang (SL), sedangkan metode penyuluhan pertanian yang termasuk kategori tinggi adalah Temu Wicara dan Studi banding.

2. Metode penyuluhan pertanian Demplot, Anjangsana, Pelatihan, Sekolah Lapang, Studi anding dan Temu Wicara secara keseluruhan berpengaruh dan siqnifikan dalam meningkatkan pengetahuan dan keterampilan petani.

Dari hasil temuan penelitian yang telah dilakukan diatas, maka kami menyarankan beberapa hal, antara lain :

1. Bagi Petani, bahwa Metode penyuluhan pertanian hendaknya dapat diikuti secara baik oleh petani khususnya kegiatan Demplot, anjangsana, pelatihan dan sekolah lapang.

2. Bagi Penyuluh, bahwa hendaknya metode anjangsana yang banyak dilakukan oleh penyuluh harus lebih diintesifkan serta materi kunjungan anjangsana tersebut juga disesuaikan dengan permasalahan dan kebutuhan petani.

3. Bagi Pemerintah atau Dinas terkait, bahwa metode studi banding dan temu wicara hendaknya dilaksanakan berdasarkan perencanaan bottom up atau sesuai dengan kebutuhan dan permasalahan yang dihadapi oleh petani. 


\section{DAFTAR PUSTAKA}

Altin Travino Ukar, 2013. Metode Demonstrasi sebagai Metode Penyuluhan Yang aling Efektif di Nusa Tenggara Timur. Makalah Seminar Penyuluhan Pertanian, Universitas Sebelas Maret, Surakarta.

Andi Purwono, 2013. Metode dan Media Penyampaian Informasi Penyuluhan. STTP, Malang

Anna Fatdiya, Sitti Aminah, Yatri Indah Kusumastuti, 2016. Penerapan Metode Teknologi Pertanian dan Hubungan Dengan Ketahanan Pangan Rumah Tangga Petani. Jurnal Penyuluhan, IPB, Vol. 12, No. 2. Bogor.

Danang Sudarso, Widya Prakoso Joyo Widodo, 2014. Strategi Peningkatan Kinerja Penyuluh Pertanian Dalam Pengembangan Agribisnis di Kab Jember. Jurnal Penyuluhan, IPB Vo. 10, No 2, Bogor.

Dodi Kurniawan, 2014. Manfaat Pelaksanaan Studi Banding. Universitas Negeri Yogyakarta (UNY), Jogya.

Departemen Pertanian. 2012. Pedoman Penyusunan dan Pelaksanaan Program Penyelenggaraan Penyuluhan Pertanian. Jakarta (ID): Departemen Pertanian.

Harinta YW. 2011. Adopsi Metode Pertanian di Kalangan Petani Di Kecamatan Gatak Kabupaten Sukoharjo. Jurnal Agrin. 15(2): 164-174.

Kusmiyati, Ait Maryani dan Dedy Kusnadi, 2014. Kinerja Penyuluh Pertanian PNS Dalam melaksanakan Tupoksi di Kabupaten Bogor, Jurnal Penelitian, IPB, Bogor.

Mardikanto, Totok. 1993. Sistem Penyuluhan Pertanian. UNS press. Surakarta.p Ninuk Purnaningsih, Basita Ginting, Margono Slamet, Asep Saefuddin, dan Soedijanto Padmowiharjo, 2012. Faktor-Faktor Yang Mempengaruhi Adopsi Metode Pola Kemitraan Agribisnis Sayuran di Jawa Barat. Jurnal Penyuluhan, IPB, Vol. 2, No 2, Bogor.

Pangerang, 2012. Makalah Penyuluhan Pertanian di Kabupaten Maros. Badan Penyuluhan dan Ketahanan Pangan Kab. Maros, Maros.

Syahputra AW, Hariadi SS. 2012. Pengaruh Peran Penyuluh dan Kearifan Lokal Terhadap Adopsi Metode Padi Sawah di Kecamatan Montasik Kabupaten Aceh Besar. Jurnal KANAL. 1(1): 85-101.

304 | Andi Nur Imran; Muhanniah; Rini Widiati Giono; Metode Penyuluhan ... 